\title{
The Differences between Chinese and Western Education
}

\author{
Yuqing $\mathrm{He}^{*}$, Jiaoyang Nie \\ Yangtze University, Jingzhou 434000, China \\ Email: *281727452@qq.com, "117981734@qq.com
}

\begin{abstract}
The purpose of this paper is to figure out the successful experience of western educational model that act as a reference for traditional Chinese education and the reform of Chinese educational model and method. Comparison is carried out on school education and family education between China and western countries. For school education, the comparison is carried out on the basic method, teaching model and enrollment system; for family education, the comparison is carried out on cultivating consciousness, psychological cultivation and responsibility education.
\end{abstract}

Keywords: Chinese and American education, differences, education essence.

\section{Introduction}

As economy developed rapidly, it is difficult for the graduates who graduate easily to get employed. So it is obvious that Chinese educational system need to be reformed. However, generations may be affected by this reform, we should be cautious about the way to carry out reform. The author used to study abroad several years and deeply sensed the essential differences between Chinese and foreign education. Thus, basic differences between Chinese and foreign education have been lay out according to his own observation. We have to admit that the educational theory and system of foreign countries are more advanced than those of China. Nevertheless, we Chinese need to improve the foreign model and method and construct one that meets the needs of Chinese people. In this way, make it better serve the society and carry out reform.

\section{School Education}

Students' knowledge is got from school education mainly. Teachers influence the students most during the period of a dozen years' study at schools (primary school, middle school, high school and university). Those influences are both positive and negative. The methods applied by teachers, their words and smile all can have an effect on students or even change their lives. Furthermore, school is a media for students to communicate with each other. Most things in their lives are happened here, which also serves as evidence.

\subsection{Differences in Education Methods}

We are familiar with the word "cramming education" which vividly describes the condition of Chinese education at that time. From its name, we can know what it reflects. Teachers crammed knowledge to students, while students just listened to it. What they learned was only the knowledge on textbooks and the exact answer of questions. Students instructed by this method, might have no ability of independent thinking and lose their interest in learning. However, teaching method applied in abroad is heuristic education. That is to say, students will not be offered answer of the question they need to work it out on their own. What's more, there may not exist a fixed answer of question. Every single student has their own point of view and thinking model, so their answers vary a lot. Those teachers encourage students to make full use of their imagination instead of giving a standard answer. In foreign countries, what teachers want to see on the test paper is their techniques towards examination, not their answer. In this way, not only will students become more interested in their study, they will be more creative in thinking. Students find problems and solve them on their own. If things continue this way, they will become original in thinking, more open-minded and imaginative. 


\subsection{Differences in Class Teaching Models}

When studied abroad, the author experienced a class teaching model totally different with that in China. Teachers did not lead the class, they would offer the subject of next class to students and let them do research before it. Then, they were required to give a presentation on the class. If there was anything wrong with them, teachers were there to help them and give complementarities. In this way, harmonious atmosphere in class came into being and teachers and students became friends. So it can not only help students get a good knowledge of the subject, but also make them draw inferences about other cases from one instance and know other things related. Because they made presentation towards the whole classes, they should prepare for answering the questions other classmates might ask. During the preparation, they could learn knowledge, be more eloquent and braver. At the same time, they could have the capability to understand and summarize knowledge. What they learned from it was not just the knowledge taught by teacher, they might come across things that they would meet up with in society. What the Chinese students get are only answers of questions, while in abroad, students can realize their own problems and know other things related during research. Meanwhile, making presentations in class help them be more out-going, original in thinking and imaginative. In the face of people, they will speak out his own opinion instead of saying nothing because of stage fright.

\subsection{Differences in Enrollment Systems}

Students in China are educated to "keep studying hard and make progress", while parents' understanding of these words is to make better scores in test. A student with good scores is considered to be knowledgeable and excellent in thinking. But can it be true? If a student shows unbalanced learning of his subjects or can't do well in his exam as usual, he may lose the opportunity to be admitted by college or university. In this way, many specific students and those who cannot play spot will have no chance to go further study. What a pity! In foreign countries, there are more geniuses produced by their enrollment. Usually, they won't look down up on those who just do well in a single subject, while instead, they encourage them to do what they are interested in. The enrolment of a student is not based on his score in test. Test score just accounts for few points. Most of their judgments are according to students' behavior in oral quiz. They want to get knowledge of students' Language organizational capacity, skills of speaking, behavior and professional knowledge through an oral quiz. While those are not easily knew by a paper test only. After being admitted, they total scores are given on the basis of their contribution which is most needed in society, instead if on their scores in test. With this system, students can easily find out what they are interested in. Only when they have their interests, can they be active in learning. In China, we do not conduct quality education. It has resulted in the fact that many students can get good scores in test, while they cannot take good care of themselves. What's worse, their capacity in communication and expression is lower than others at their ages. Not the students that do well in test will stand out, while it is those who are qualified in many aspects. For example, leadership, practical ability, cooperative ability. Only one that are equipped with all these can have a better future.

\section{Family Education}

References In our traditional concept, a student with a bad score and moral cultivation is due to a bad school education. However, we forget that family contributes more to a child than school. In China, parents often neglect or do little in education. From the moment they are born to their entering in society, they live with their families. So they learn from their parents' behavior. If they behave well when young, they will do the same when growing up, vice versa. Social competition does not refer to that of knowledge and intelligence only. However, it is more of will psychological states and behavior. practical competent just as same as adults. They can help foster an environment that is good to cultivate children's creative capacity and discoverability with tolerance. They support children's exploration to new things and encourage them to put forward different opinions. Even though they know children may do wrong with something, they will not figure it out directly, while instead, they prefer to make them realize their own faults during the procedure and then correct them. While on the contrary, children in China are educated to reserve their own opinions. Parents usually do not support their children's exploration towards things new which they think is mischievous and make them stop doing so any more. 


\subsection{Differences in Cultivating Consciousness}

In abroad, children are trained to be more independent in living skills and ability when they are young by their parents. They do not design the future road of their kids, but instead, they focus on free development of their kids to make them an independent social person and have the ability to live in all kinds of environment. Their starting point is to make the kids with pioneering spirit and earn one's own living. During the process of doing housework, they will become an independent person with social responsibility. Many parents in China have great ambitions for their children, so their education method is beyond their children's standing ability mostly. They are exasperated at children's' failure to make good. Parents take good care of their children and focus mostly on their study. However, they care little or even do not care about their independent capacity, social adaptation ability, psychological states, moral quality and civic consciousness. It seems that study well means everything. Before they becoming adults, parents do everything for them, such as cooking, washing clothes, cleaning, and raising money for their further study abroad or in China, their marriage and their children. There is no doubt that parents all want their kids to be successful and happy. While under this kind of education method, children cannot be happy. Because the social competition is not just about knowledge and intelligence, while it is about will, psychological states and behavior instead.

\subsection{Differences in Psychological Cultivation}

Parents in foreign countries focus more on the cultivation of children's mentality. So they do emotion communication with their kids and care about what they really need. They attach great importance to happy education. They discuss questions together and in this way, children can share happiness and sorrows with their parents. Psychological study shows that healthy mental state contributes a lot to children's growth and to shaping healthy personality. They carry out basic education from daily behavior and emotion and let them know how to respect others. While parents in China care about their kids on their physiological requirements, they even ignore their mental needs and do not train them with healthy mentality and will and good personality. As a result, it can make children have low psychological endurance to a large extent. They cannot stand the pressure and setback in their lives. Even a small thing can make them sad, dispirited, self-abandoned, become traitorous, run away from home or even take their own lives. Parents and teachers in kindergartens often do not follow the principle of children's mental development, habit and interpersonal communication. Education that does not in accordance with the state of children's growth make them has little awareness of morality and society.

\subsection{Differences in Responsibility Education}

We have not done a good job in responsibility education of students. If we do not train them a conscientious man from their early age, they will become irresponsible in whole lives. Not only can school education train them to be conscientious to their own words, people, society, and their nation. It can also be shaped from family environment and atmosphere. But the word that it is the responsibility for school to educate children said by parent shows that they ignore the influence of family to children. While parents in foreign countries make their kids do things by their own in order to make them more responsible. Children in China are spoiled by their parents and grandparents. They do not need to do any housework and before and after class there will be someone picking them up. On the contrary, in foreign countries, unless they have something urgent, they will take school bus. It will help them integrate in classes and build a concept of time. Every student in school is equal; no one is superior to others. It can help avoid unrealistic comparison. For example, at the airport when a family with children goes travelling, we can see parents need to carry bags as well as children having snacks in their arms or by their hands in a Chinese family. While the foreign one is everyone, including children needs to carry his own bags in which there are toys and snacks of his own. From this small thing, we can know that children in foreign countries have learned to take responsibility at an early age, while those in China haven't yet. 


\section{Summary}

The differences between Chinese and foreign education make those children have totally different experiences. No all the foreign education methods are perfect. Both have advantages and disadvantages. But parents and teachers need to check their own method and way of education. They should give more choices to children and equip them with practical ability and make them more innovative. At the same time, let them go further in what they are interested in. Kids should be trained to be independent and responsible by their parents when they are young. In this way they can have a better life and future and have the ability to think independently and to solve problems.

\section{References}

1. Brown H D.Principles of Language Learning and Teaching $[\mathrm{M}]$. Beijing:Foreign Language Teaching and Research Press, 2001.

2. Coulthard M.An Introduction to Discourse Analysis [M].London: Longman,1985.

3. Finocchiaro M,Brumfit C.The Functional-Notional Approach: From Theory to Practice [M].New York: Oxford University Press, 1983.

4. Halliday M A K.Learning How to Mean: Exploration in the Development of Language[M]. London: Edward Arnold, 1975 .

5. Savignon S J.Communicative Language Teaching: Linguistic Theory and Classroom Practice [M].Savingnon S J.Interpreting Communicative Language. 